\section{The Commonwealth Solar Observatory, Canberra}

ThE first report of the present Director of the Mt. Stromlo Observatory refers to the period May 1939April 1940, though it also sketches the history of the Observatory since its establishment in 1910, and gives a brief account of the main observational programmes carried out since the first Director's appointment in 1924. The observations of solar radiation begun in 1926 have been completed, and a discussion of the results is promised. One of the most interesting conclusions is that the correlation between total solar radiation and duration of bright sunshine is so close as to be useful for derivation of the first quantity, the direct observation of which is difficult, from the second, which is a standard meteorological datum. Spectrohelioscopic and visual observations of the sun have been directed respectively to the detection and mapping of bright solar eruptions, several spectrograms of which have been obtained during 1939. As compared with flash spectra, these show a puzzling enhancement of low-excitation $\mathrm{Fe} I$ and $\mathrm{Fe}$ II lines.

A new programme of stellar observations is planned for the Reynolds 30-inch reflector which has been converted from Newtonian to Cassegrain form for the purpose. A single-prism spectrograph for spectroscopic parallaxes and a photo-electric photometer have been made for use at the Cassegrain focus. The work on cosmic radiation and atmospheric physics with which the name of the Observatory is especially associated has been carried on with a few modifications, chief among which are the discontinuance of the observations of atmospheric electricity and night-sky luminosity, and an extension of the work on cosmic rays and the ozone content of the atmosphere. With the establishment five miles away of an official Commonwealth meteorological station, many of the routine meteorological observations have been discontinued, though measurements having a direct bearing on other Observatory programmes are still being carried out. An impressive list of papers published during the year shows that the establishment is more than maintaining its high standing amongst southern hemisphere observatories.

\section{New Russian Botanical Gardens}

NEw botanical gardens, attached to the Armenian Branch of the Academy of Sciences of the U.S.S.R., were recently opened in Erivan, capital of the Soviet republic of Armenia. The gardens, which have some three thousand species of plants, have grown up during the course of five years on the dry, stony, desert soil between the settlements of Avan and Kanaker, near Erivan, which has been reclaimed. One of the most interesting departments of the gardens is the section devoted to the plants of Armenia. Ultimately, some 2,600 specimens of the flora of this republic will be collected there; the section already has 350 specimens. In the centre of this section has been built a pond, resembling the high mountain lake of Sevan. In the pond have been planted specimens of water plants of Armenia. In the southern part of the gardens the Geographical
Department is concentrated. More than half the area of the gardens is occupied by arboreal plants. The flower gardens are exceptionally rich; in the Avenue of Roses and Fountains more than a hundred varieties of roses have been planted.

\section{Health in Sierra Leone}

In the latest annual report of the medical services of Sierra Leone, the director, Dr. W. P. H. Lightbody records a satisfactory state of general health among a population of about 100,000 and an absence of major epidemics. Nutrition in the undisturbed tribal communities is fairly satisfactory, but in Freetown, the capital, with a population of 55,000 , and the adjacent villages there is some evidence of qualitative defects in diet, mainly an insufficiency of protein, Among the 250 European officials resident, the average annual sick leave per resident was $6 \cdot 46$ days, almost exactly the same as that of the 1,000 African officials. Only 3 European officials were invalided home during the year. Among the 495 European non-official residents the total number who went on sick leave was 73. The most frequent causes of death among the population in Freetown was malaria, which causes nearly twice as many deaths as tuberculosis, the second largest cause of mortality. Malaria also accounts for $\mathbf{4 3}$ per cent of the hospital cases in the colony.

\section{The Wellcome Foundation Ltd.: Appointments}

Dr. R. A. O'Brien, who joined the staff of the Wellcome Physiological Research Laboratories at Beckenham in 1910 and became director in 1914, retired at the end of 1940 . Dr. J. W. Trevan, who became head of the Pharmacological Section in 1920, has been appointed to succeed him. Dr. S. Smith, head of the Experimental Research Department and manager of the Wellcome Chemical Works at Dartford, has been appointed director of the Wellcome Chemical Research Laboratories at Beckenham. Dr. W. M. Duffin has also been transferred from Dartford to Beckenham. Mr. J. Russell has been appointed manager of the Wellcome Chemical Works. Mr. R. L. Grant has been appointed head of the Chemical Manufacturing Department on the retirement of Mr. W. Taylor.

\section{Announcements}

Mr. Axel L. Wenner-Gren, a Swedish industrialist, has given a cheque for ten thousand dollars to the University of Toronto for the extension of the work of its Geophysies Department.

THE following vital statistics for Scotland for the quarter ending June 30, 1940, have been published by the Registrar-General : The birth-rate was $18 \cdot 6$, the lowest ever recorded for the second quarter of any year since the institution of national registration in Scotland; the death rate was 12.8 , and the infantile mortality 67 , which is 1 below the average for second quarters of the year. 